\title{
An Investigation of the Attitudes and Competence Perceptions of First- and Fourth-Year Pre-service Physical Education Teachers Regarding Teaching
}

\author{
Mümine Soytürk ${ }^{1}$, Özden Tepeköylü Öztürk ${ }^{2}$ \\ ${ }^{1}$ Faculty of Sport Sciences, Celal Bayar University, Manisa, Turkey \\ ${ }^{2}$ Faculty of Sport Sciences, Pamukkale University, Denizli, Turkey \\ Correspondence: Özden Tepeköylü Öztürk, Faculty of Sport Sciences, Pamukkale University, Denizli, Kınıklı Campus, \\ 20020, Turkey.
}

Received: February 23, 2019

Accepted: March 6, 2019 Online Published: March 13, 2019

doi:10.11114/jets.v7i4.4141

URL: https://doi.org/10.11114/jets.v7i4.4141

\begin{abstract}
The aim of this study was to investigate the attitudes and competence perceptions of first- and fourth-year preservice physical education teachers regarding teaching. A total of 262 preservice physical education teachers, of whom 126 $(\% 48,1)$ were in the first year and $136(\% 51,9)$ were in the fourth year $(\bar{x}($ age $)=21,06 \pm 2,15)$ participated in the study. The "Attitude Toward Teaching Scale" (ATTS) and "Preservice Teachers' Self-Efficacy Perception Scale" (PTSEPS) were used as the data collection tools, and a "Personal Information Form" (PIF) was used to obtain the independent variables of the study. The T-test and Pearson correlation test were used in the data analysis. As a result of the analyses, it was observed that the attitudes of the first-year students towards teaching were more positive than those of the fourth-year students. Competence perceptions were found as high in the fourth grade. According to the gender factor, significant difference was observed in both attitudes towards teaching and perceptions of competence between first- and fourth-year. When the relationships between the two dependent variables were examined, it was determined that there was a moderate positive correlation between the attitudes and competence perceptions of both the first-year students and the fourth-year students with regard to teaching. In order for preservice teachers to maintain a positive attitude towards teaching, it is considered that they should be supported with curricular training programs during the student period, and through in-service training throughout their professional lives after graduation.
\end{abstract}

Keywords: perceptions of attitudes, perceptions of competence, preservice teachers, physical education, teaching

\section{Introduction}

In school environments in which desired cultural values are acquired in line with national ideology, it can be said that the importance of teachers' qualities and of positive attitudes related to the profession is undeniable. According to the study, "General Competencies for the Teaching Profession", presented by the Ministry of National Education, in the research entitled "Survey of Professional Status in Turkey" supported by the Turkish Scientific and Technological Research Council (TSTRC), the teaching profession is regarded as the fourth highest occupation in terms of status in Turkey (Ministry of National Education, 2017). In this context, higher education institutions that train teachers are in the position of enabling the acquisition of thorough knowledge and skills in teacher candidates and of preparing them for the profession.

A physical education teacher can be regarded as the source of all learning related to physical education and sport in schools. A qualified physical education teacher must be able to present knowledge, attitudes and behaviours that meet the demands of both students and managers in a school atmosphere. Generally underlying appropriate behaviour are positive attitudes. According to the definition by Odabaşı and Barış (2012), attitude is the tendency to react in a positive or negative way to a specific individual, object or environment. (Senemoğlu, 2000), however, defines attitude as an acquired internal state that affects a person's choice in his/her individual actions towards any things, individuals or events and in many different situations. The attitudes of preservice teachers towards their profession can form the basis for them to be able to carry out this profession in a qualified manner. Indeed, research in this direction has been carried out in many studies in different areas of teaching. One of the pioneer studies made in the field of physical education teaching was carried out by Saracaloğlu (1992). Another important study conducted in the field of physical education 
teaching was made by Pehlivan (2010). He examined the physical self-perceptions of preservice physical education teachers and their attitudes towards the teaching profession. The research findings revealed a moderate level of attitudes towards teaching. Semerci \& Semerci (2004) concluded that preservice physical education teachers generally had positive attitudes towards the profession. Göktaş and Yanık (2015) determined differences in attitudes of students in physical education and sports school towards the teaching profession with regard to the gender and class level variables. Similarly, in another study conducted by Cinpolat, Alıncak ve Abakay (2016), it was determined that the participants' attitudes towards the teaching profession were positive. Yalız (2010) also revealed that the attitudes of students in the Physical Education and Sports Teaching Department towards the teaching profession were positive and at a high level. Sandıkçı and Öncü (2013)conducted research into determining and comparing the competence perceptions and attitudes of prospective teachers in physical education and other fields regarding the teaching profession. Zengin, Karagün, Öztürk and Sarı (2017) did not find a difference between the attitudes of preservice teachers of physical education and sports and of other subjects with regard to the teaching profession. Toprak and Saraç (2014) reported that attitudes of candidates applying for special skills examinations were generally positive. Ünlü (2011) developed an attitude scale for the physical education teaching profession with preservice physical education teachers. Moreover, Yanık and Çamliyer (2013) developed an attitude scale for the physical education teaching profession for students in middle school.

The attitudes of teacher candidates towards the teaching profession have been discussed in different contexts in almost all fields of teaching. Some of these deal with preservice teachers in Turkish teaching (Akkaya, 2009), classroom teaching (Açışlı \& Kolomuç, 2012; İyison \& Onur Sezer, 2017; Nalçaci \& Sökmen, 2016), the child development programme and preschool teaching (Yavuzekinci \& Tatlı, 2015), mathematics teaching (Taşdemir, 2014) and chemistry teaching (Kutucu \& Ekiz, 2011).

There are relatively few studies that deal with an examination of the self-perceptions of preservice physical education teachers, yet they can be regarded as an important indicator of affective domain characteristics. In the investigation carried out by Sandıkçı \& Öncü (2013), it was concluded that the competence perceptions of preservice physical education teachers differed according to the variable of academic success. In an examination of prospective teachers' self-perceptions, Ekici (2008) examined the perceptions of preservice classroom teachers. The research findings indicated that the levels of the preservice classroom teachers' perceptions of their own competence did not significantly differ statistically according to gender, general academic success level or type of high school graduated from. Çapri \& Çelikkaleli (2008), however, determined that the variables of gender, syllabus and faculty had an effect on teacher candidates' competence beliefs. Preservice physical education teachers' attitudes towards sport may also affect both their attitudes towards teaching and their competence perceptions (Yanık, 2018).

In the light of the information about preservice teachers' attitudes towards the profession and their personal competence perceptions, the aim of this study is to investigate the attitudes and competence perceptions of first- and fourth-year preservice physical education teachers with regard to teaching.

\section{Method}

\subsection{Participants}

First- and fourth-year students who had begun their education in two consecutive years in the Physical Education and Sports Teaching Department at Manisa Celal Bayar University took part in the study during the 2016-2017 academic year. Data were gathered from the first-year students at the beginning of the first semester, and from the fourth-year students at the end of the eighth semester. A total of 262 preservice physical education teachers, of whom $126(48.1 \%)$ were in the first year and $136(51.9 \%)$ were in the fourth year $\left(\bar{x}_{\text {age }}=21.06 \pm 2.15\right)$ participated in the study. $153(58.4 \%)$ of the participants were male, while 106 (44.6\%) were female.

\subsection{Tools and Materials}

\subsubsection{Attitude Toward Teaching Scale}

The "Attitude Toward Teaching Scale" (ATTS), developed with the aim of evaluating the attitudes of preservice teachers towards the teaching profession, was used. This scale was developed by Erkuş, Sanl1, Bağll, and Güven, (2000) and consists of 22 items. The scale has a single-dimension structure and 13 of the items are scored inversely. The items are scored ranging from "definitely applies to me" (5) to "definitely does not apply to me" (1). The Cronbach Alpha internal consistency coefficient for the scale was determined as 0.99. In the present study, the Cronbach Alpha internal consistency coefficient for the scale was determined as 0.938 .

\subsubsection{Preservice Teachers' Self-Efficacy Perception Scale}

The "Preservice Teachers' Self-Efficacy Perception Scale" (PTSEPS), developed by Çakır, Erkuş and Kılıç (as cited in Sandıkçı and Öncü, 2013) with the aim of measuring preservice teachers' beliefs regarding their own professional competence, was used. The scale consists of 30 items. The items in this scale are scored ranging from "definitely does 
not apply to me" (1) to "definitely applies to me" (5) and are grouped in 5 categories. The scale has a single-dimension structure and contains no inversely-scored items. The Cronbach Alpha internal consistency coefficient for the scale is 0.80 (Sandıkçı and Öncü, 2013). In the present study, the Cronbach Alpha internal consistency coefficient for the scale is 0.953 .

\subsubsection{Personal Information Form}

Demographic information regarding the participants was obtained via a Personal Information Form. In the form, questions related to gender, class level and perception of family income are included. Choices between low, medium and high perceptions of family income were offered, and since three people from each of the two groups stated low income perceptions and no perceptions of high income were recorded in either group, data suitable for comparison were not obtained.

\section{Results}

\subsection{Statistics and Data Analysis}

SPSS 22 statistical software was utilized for the data analysis. Data were obtained using frequency, arithmetic mean and standard deviation. Also, t-test was used for analysis of the difference between independent groups, while the Pearson Correlation test was used for the correlation analysis. Type 1 error was set at 5\%.

Table 1. Comparison of Preservice Teachers' Attitudes and Self-Efficacy Perceptions with Regard to Teaching According to Class Level

\begin{tabular}{lccccccc}
\hline Dependent Variable & Group & $\mathbf{n}$ & $\bar{x}$ & sd & df & t & p \\
\hline \multirow{2}{*}{ Attitudes Towards Teaching } & 1st year & 126 & 92,54 & 14,315 & \multirow{2}{*}{260} & 4,166 &, $001 *$ \\
& 4th year & 136 & 83,48 & 20,150 & & & \\
\hline \multirow{2}{*}{ Self-Efficacy Perceptions } & 1st year & 126 & 120,99 & 22,471 & \multirow{2}{*}{, $003 *$}
\end{tabular}

Table 1 shows the comparison between classes of the preservice teachers' ATTS and PTSEPS scores. Accordingly, it was determined that the attitude scores of the first-year students with regard to teaching were statistically significantly higher than those of the fourth-year students. Self-efficacy perceptions of the fourth-year preservice teachers' were found statistically significantly higher than those of the first-year students.

Table 2. Comparison of Male Preservice Teachers' Attitudes and Self-Efficacy Perceptions with Regard to Teaching

\begin{tabular}{|c|c|c|c|c|c|c|c|}
\hline Dependent Variable & Group & $\mathbf{n}$ & $\bar{x}$ & sd & df & $\mathbf{t}$ & $\mathbf{p}$ \\
\hline \multirow{2}{*}{$\begin{array}{l}\text { Attitudes Towards } \\
\text { Teaching }\end{array}$} & 1 st year & 75 & 89,96 & 15,259 & \multirow{2}{*}{151} & \multirow{2}{*}{3,365} & \multirow{2}{*}{, $001 *$} \\
\hline & 4th year & 78 & 80,47 & 19,286 & & & \\
\hline \multirow{2}{*}{ Self-Efficacy Perceptions } & 1st year & 75 & 118,81 & 24,224 & \multirow{2}{*}{151} & \multirow{2}{*}{2,110} & \multirow{2}{*}{,036* } \\
\hline & 4 th year & 78 & 126,07 & 17,799 & & & \\
\hline
\end{tabular}

The comparison of the male preservice teachers' ATTS and PTSEPS scores is shown in Table 2. Accordingly, it was determined that the attitude scores of the male in first-year students with regard to teaching were statistically significantly higher than those of the male in fourth-year. Self-efficacy perceptions of the male in fourth-year preservice teachers were found statistically significantly higher than those of the first-year students.

Table 3. Comparison of Female Preservice Teachers' Attitudes and Self-Efficacy Perceptions with Regard to Teaching

\begin{tabular}{llllllll}
\hline Dependent Variable & Group & $\mathbf{n}$ & $\bar{x}$ & sd & df & t & p \\
\hline Attitudes Towards & 1st year & 51 & 96,35 & 11,954 & \multirow{2}{*}{107} & 2,670 &, $009^{*}$ \\
Teaching & 4th year & 58 & 87,53 & 20,739 & & & \\
\hline \multirow{2}{*}{ Self-Efficacy Perceptions } & 1st year & 51 & 124,19 & 19,398 & \multirow{2}{*}{02,211} &, $029^{*}$ \\
& 4th year & 58 & 131,77 & 16,377 & & & \\
\hline
\end{tabular}

The comparison of the female preservice teachers' ATTS and PTSEPS scores is shown in Table 2. Accordingly, it was determined that the attitude scores of the female in first-year students with regard to teaching were statistically significantly higher than those of the female in fourth-year students. Self-efficacy perceptions of the female in fourth-year preservice teachers were found statistically significantly higher than those of the first-year students. 


\section{Discussion}

The research findings obtained reveal that the preservice teachers had positive attitudes and perceptions of competence related to the teaching profession. It was expected that in particular, the scores of the candidates studying in the teaching department as a result of the aptitude exam would be positive. In order to study in this department, it is necessary to succeed in competition with many other people. At the same time, the results can be interpreted to state that their teaching identities had taken precedence over their sporting identities.

Based on the class variable, the findings for attitudes and perceptions generally correspond to findings in the literature. Pehlivan (2010) reported that attitudes towards teaching were more positive in lower grades than in higher grades. However, Göktaş and Yanık (2015) found that scores of fourth grades were more positive than those of second grades. In contrast with these two results, Yalız (2010) argued that the class variable did not create a difference with regard to attitude towards teaching. In their study, in which preservice science, mathematics and classroom teachers' perceptions of their own competence were compared, Altunçekiç, Yaman ve Koray (2005)determined that their levels of belief in their own self-efficacy related to teaching were lower in first grades than in the other class levels. In our study, no difference was determined. Additionally, in the study it was found that the fourth year students' perceptions of competence were higher than the first year ones. The different outcomes of similar studies may be considered to be due to the fact that potential teaching perceptions of candidates attending different universities were affected by the possibilities of being appointed as teachers as class level increased. Moreover, in lower grades, the perception of teaching may be due more to an association with only a yearned-for, respected and dream concept of the profession, whereas final-year students may also experience the difficult aspects of teaching during their School Experience and Teaching Practice courses.

Regarding the gender variable, even studies conducted a quarter of a century ago revealed that female teacher candidates had more positive attitudes towards teaching than male candidates (Saracaloglu, 1992). Later studies also produced similar results (Baykara Pehlivan, 2008); Pehlivan, 2010; Yalız, 2010; Göktaş \& Yanık, 2015; (Cinpolat et al., 2016). In a study examining preservice teachers' attitudes, it was found that female candidates had significantly higher scores for love of the profession and compatibility with the profession than male candidates did (Durmuşçelebi, Sayg1, \& Yıldız, 2017). In this case, the need to encourage and support women in guiding them towards this profession arises. On the other hand, it also becomes clear that there is a need for additional influence in curricular practices so that male preservice teachers' attitudes can be raised to a similar level. In the study, attitudes towards teaching of first year were found as higher in both genders. On the other side, the perception of competence related to teaching was found to be higher in fourth years. It may be increased the competence perception, curriculum has been followed in the Physical Education Department for four years and additionally training provided.

Another finding obtained in the study was that the attitudes and competence perceptions of the preservice physical education teachers regarding the teaching profession were correlated with each other. This relationship was found to be positive and moderately significant (Büyüköztürk, 2002) for both dependent variables. In their study, Sandıkçı and Öncü (2012) examined the relationship between attitudes and competence perceptions related to teaching in preservice physical education teachers and other preservice teachers. A moderate, positive correlation between these two variables was also recorded as a result of their study. As a result of determining the state of teachers' affective domain needs in different populations with variables such as attitudes towards the profession, it may be possible to increase the correlation of these variables with applied studies. In particular, perceptions of competence can be supported during the implementation process.

\section{Conclusion}

In conclusion, the attitudes of the preservice physical education teachers towards their profession were found to be positive, and higher average scores were obtained especially in females. Furthermore, perceptions of competence were determined to be correlated with attitudes towards teaching. Accordingly, in order for preservice teachers to maintain a positive attitude towards teaching, it is considered that they should be supported with curricular training programs during the student period, and through in-service training throughout their professional lives after graduation.

\section{References}

Açışl1, S., \& Kolomuç, A. (2012). Study of the would-be class teachers' attitude towards the profession. Journal of Research in Education and Teaching, 1(2), 2146-9199. Retrieved from http://www.jret.org/FileUpload/ks281142/File/30.acisli.pdf

Akkaya, N. (2009). An investigetion of prospective teachers' attitudes regarding teaching various in terms of variables. Dokuz Eylul University Journal of Buca Faculty of Education, 25, 35-42. Retrieved from http://acikerisim.deu.edu.tr/xmlui/bitstream/handle/12345/219/192.pdf?sequence=1\&isAllowed=y 
Altunçekiç, A., Yaman, S., \& Koray, Ö. (2005). The research on prospective teachers' self- efficacy belief level and problem solving skills. Gazi University Kastamonu Education Journal, 13(1), 93-102. Retrieved from https://scholar.google.com.tr/scholar?q=Öğretmen+Adaylarının+Öz-Yeterlik+İnanç+Düzeyleri+Ve+Problem+Çöz

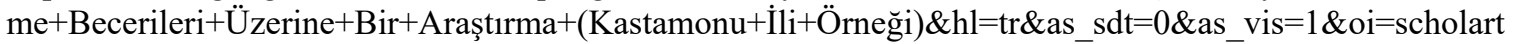

Baykara Pehlivan, K. (2008). A Study on Pre-service Classroom Teachers' Socio-cultural Properties and Their Attitudes toward Teaching Occupation as a Subject. Mersin University Journal of the Faculty of Education, 4(2), 151-168.

Büyüköztürk, Ş. (2002). Sosyal bilimler için veri analizi el kitabi (2. Edition). Ankara: Pegem A Yayıncılık.

Çapri, B., \& Çelikkaleli, Ö. (2008). Investigation of preservice teachers' attitudes towards teaching and professional self-efficacy beliefs according to their gender, programs, and faculties. İnönü Üniversitesi Eğitim Fakültesi Dergisi, 9(15), 33-53. https://doi.org/10.17679/IUEFD.18403

Cinpolat, T., Alıncak, F., \& Abakay, U. (2016). Examination of the attitudes of physical education and sports college students towards teaching profession. Gaziantep University Sports Sciences Journal, 1(1), 38-47. Retrieved from http://dergipark.gov.tr/download/article-file/225373

Durmuşçelebi, M., Sayg1, E., \& Yıldız, N. (2017). Investigation of teacher candidates' attitudes towards teaching profession. International Journal of Society Researches ISSN:2528-9527, 7(12), 10-31. Retrieved from http://dergipark.gov.tr/download/article-file/317470

Ekici, G. (2008). The effects of the classroom management lesson on preservice teachers ' teacher sense of self-efficacy. H. U. Journal of Education), 35, 98-110. Retrieved from http://dergipark.gov.tr/download/article-file/87571

Erkuş, A., Sanlı, N., Bağl1, M. T., \& Güven, K. (2000). Developing an attitude scale toward teaching as a profession. Education and Science, 25(116), 27-33.

Göktaş, Z., \& Yanık, M. (2015). Students of Physical Education and Sports Attitudes Toward Physical Education Study of Teaching Profession. International Refereed Academic Journal of Sports, 05(16), 39-39. https://doi.org/10.17363/sstb.20151610873

İyison, G., \& Onur Sezer, G. (2017). Investigation of the relationship between teachers "attitudes towards teaching profession and elementary school teachers" competencies. The Journal of Academic Social Science, 5(50), 528542. https://doi.org/10.16992/ASOS.12588

Kutucu, E. S., \& Ekiz, B. (2011). Pre-service chemistry teachers attitudes and concerns towards teaching profession. E-Journal of New World Sciences Academy, 6(1), 736-743.

Ministry of National Education. (2017). General Competencies for the Teaching Profession.

Nalçaci, A., \& Sökmen, Y. (2016). The reasons for pre-service teachers to prefer teaching profession and its relationship with their attitudes toward this profession. Ahi Evran University Kirşehir Education Faculty Journal (KEFAD), 17(3), 717-727. Retrieved from http://kefad.ahievran.edu.tr/InstitutionArchiveFiles/f44778c7-ad4a-e711-80ef-00224d68272d/d1a3a581-af4a-e71180ef-00224d68272d/Cilt17Sayi3/JKEF_17_3_2016_717_727.pdf

Odabaşı, Y., \& Barış, G. (2012). Tüketici Davranışı. İstanbul: Mediacat Yayıncılık.

Pehlivan, Z. (2010). Analysis of physical self-perceptions of physical education teacher candidates and their attitudes toward teaching profession. Education and Science, 35(156), 126-141.

Sandıkçı, M., \& Öncü, E. (2013). Determination and comparison of physical education and the other pre-service teachers' self-efficacy beliefs and attitudes toward teaching profession. Pamukkale Journal of Sport Sciences, 4(1), $135-151$.

Saracaloğlu, A. S. (1992). The attitudes of physical educator candidates toward teaching profession. Journal of Sport Science (SBD), 3(1), 10-26. Retrieved from http://dergipark.gov.tr/download/article-file/151529

Semerci, N., \& Semerci, Ç. (2004). Attitudes Toward Teaching In Turkish. University Journal of Social Science Cilt, 14(1), 137-146. Retrieved from http://web.firat.edu.tr/sosyalbil/dergi/arsiv/cilt14/sayi1/137-146.pdf

Senemoğlu, N. (2000). Gelişim, Öğrenme ve Öğretim: Kuramdan Uygulamaya. Ankara: Gazi Kitapevi.

Taşdemir, C. (2014). To investigate the elementary mathematics teacher candidates' attitudes to the teaching profession. Journal of Computer and Educational Research, 2(3), 91-114. Retrieved from http://dergipark.gov.tr/download/article-file/174019

Toprak, N., \& Saraç, L. (2014). An examination of attitudes toward teaching profession among female and male physical education and sports department entrance examination applicants. Pamukkale Journal of Sport Sciences, 
5(2), 35-47. Retrieved from http://dergipark.gov.tr/download/article-file/174019

Ünlü, H. (2011). Developing an Attitude Scale for the Profession of Physical Education Teaching (ASPPET). Educational Sciences: Theory \& Practice, 11(4), 2005-2020. Retrieved from https://toad.edam.com.tr/sites/default/files/pdf/beden-egitimi-ogretmenligi-meslegine-yonelik-tutum-olcegi-beoyto -toad.pdf

Yalız, D. (2010). Comparison attitudes toards teaching profession of students in the department of physical education and sports teaching at Anadolu University. Beden Eğitimi ve Spor Bilimleri Dergisi, 5(1), 7-14. Retrieved from http://dergipark.gov.tr/download/article-file/370571

Yanık, M. (2018). Attitudes of University Students Towards Sport. Journal of Education and Training Studies, 6(5), 111. https://doi.org/10.11114/jets.v6i5.3047

Yanık, M., \& Çamlıyer, H. (2013). Developing an attitude scale towards profession of physical education teaching in secondary schools ( SASPPET ). International Journal of Human Sciences, 10(2), 691-705.

Yavuzekinci, M., \& Tatl1, S. (2015). Students of child development program and pre-school teaching comparison of teacher efficacy and attitudes towards the teaching profession. The Journal of Social Science, 42(5), 327-338. Retrieved from http://www.sobider.com/Makaleler/180066892_104 Mustafa YAVUZEKINCİ.pdf

Zengin, A., Karagün, E., Öztürk, F., \& Sarı, S. (2017). Investıgation of physical education teacher candidates’ teachers and other teaching profession against the attitude: the case study of Kocaeli. In 9th International Physical Education Teacher and Sports Instruction Congress. Antalya.

\section{Copyrights}

Copyright for this article is retained by the author(s), with first publication rights granted to the journal.

This is an open-access article distributed under the terms and conditions of the Creative Commons Attribution license which permits unrestricted use, distribution, and reproduction in any medium, provided the original work is properly cited. 